Original Article

\title{
Nutritional assessment of servicemen in relation to area of duty and feeding habits: a Pakistani prospective
}

\author{
Avaliação nutricional de militares em relação à área de dever e hábitos alimentares: \\ uma perspectiva paquistanesa
}

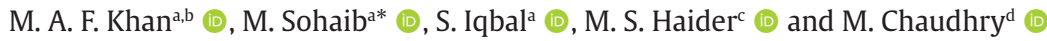 \\ aUniversity of Veterinary and Animal Sciences, Faculty of Bio-Sciences, Department of Food Science and Human Nutrition, Lahore, Pakistan \\ ${ }^{\mathrm{b}}$ Armed Forces Institute of Nutrition, R.A Bazar Lahore Cantonment, Lahore Punjab, Pakistan \\ cUniversity of the Punjab, Faculty of Agriculture, Lahore, Pakistan \\ dUniversity of Veterinary and Animal Sciences, Department of Epidemiology and Public Health, Lahore, Pakistan
}

\begin{abstract}
The present study was carried out to determine incidence of overweight and obesity in Pakistani servicemen with reference to their area of duty, feeding habits and also to identify risk factors. Accordingly, 2,501 servicemen selected from all over Pakistan using multiple stage stratified sampling protocol. Nutrition assessment performed using body mass index (BMI), waist to hip ratio (WHR) and dietary assessment using food frequency questionnaire. Collected data was analyzed using the SPSS version 25 . Regression was used to find risk factors of obesity and WHR. Results indicated that about $1 / 4^{\text {th }}$ of servicemen were smokers. Approximately, $1 / 5^{\text {th }}$ of them were overweight and about one quarter were eating fruits and vegetables for $<3$ days/ week and $<4$ days/week, respectively. Only $1 / 3^{\text {rd }}$ of them were physically active for at least $<40$ minutes per day. Age and fruits intake were significantly predicting BMI with a direct relation and vegetable intake was negatively correlated to BMI of the servicemen. Age and rank were significant predictors of WHR while, physical activity was negatively correlated to WHR. It is concluded and suggested from our study that there is a need to modify eating patterns and habits as well as improving physical activity on daily basis for healthy and long life of the servicemen.
\end{abstract}

Keywords: servicemen, nutritional status, body mass index, intake, obesity.

\begin{abstract}
Resumo
O presente estudo foi realizado para determinar a incidência de sobrepeso e obesidade em militares paquistaneses com referência à sua área de serviço, hábitos alimentares e também para identificar fatores de risco. Assim, 2.501 militares selecionados de todo o Paquistão usando protocolo de amostragem estratificada de múltiplos estágios. Avaliação nutricional realizada por meio do índice de massa corporal (IMC), relação cintura-quadril (RCQ) e avaliação alimentar por meio de questionário de frequência alimentar. Os dados coletados foram analisados por meio do SPSS versão 25 . A regressão foi usada para encontrar fatores de risco para obesidade e RCQ. Os resultados indicaram que cerca de $1 / 4$ dos militares eram fumantes. Aproximadamente, $1 / 5$ deles estava com sobrepeso e cerca de um quarto comia frutas e vegetais por $<3$ dias / semana e $<4$ dias / semana, respectivamente. Apenas $1 / 3$ deles era fisicamente ativo por pelo menos $<40$ minutos por dia. Idade e ingestão de frutas foram preditores significativos do IMC com uma relação direta e ingestão de vegetais foi negativamente correlacionada com o IMC dos militares. Idade e posição foram preditores significativos de RCQ enquanto a atividade física foi negativamente correlacionada com RCQ. Conclui-se e sugere-se a partir de nosso estudo que há necessidade de modificar os padrões e hábitos alimentares, bem como melhorar a atividade física no dia a dia para uma vida longa e saudável dos militares.
\end{abstract}

Palavras-chave: militares, estado nutricional, índice de massa corporal, ingestão, obesidade.

\section{Introduction}

The nutritional status can be stated as "The body condition with respect to diet intake; level of various nutrients in the body and the body's ability to maintain nutritional status" (Wang et al., 2014). Optimal nutrition improves physical performance and supports recovery in living organisms. Under the conditions of increased physical activity, consumption of adequate calories, macronutrients and specific micronutrients affect servicemen performance. In order to maintain nutritional status, the right food must be available at right time and must be consumed in right quantity to get optimal benefits needed for healthy living (Jayne et al., 2021; Montain et al., 2010). According to WHO,

*e-mail: muhammad.sohaib@uvas.edu.pk

Received: April 7, 2021 - Accepted: April 24, 2021 
worldwide $39 \%$ adults has been found under overweight as well as more than $13 \%$ are obese however, the trend is increasing at alarming rate ultimately contributing disease burden for the country. As per published studies regarding about global burden of disease, Pakistan ranked $9^{\text {th }}$ out of 188 countries in terms of obesity and the lancet medical journal commented since 1980, trend remained same (Tribune, 2014). Recently, studies documented obesity increasing trend in servicemen's globally. The various attributes for this global pandemic are due to reduction in physical activity as a result of non-adherence to strict military routine of physical training, as consequence fitness standard of servicemen (Military personnel) declining. All these factors leading to obesity which in turn can increase incidence of chronic illnesses like hypertension, ischemic heart disease and diabetes (Adams, 2020; Asghar et al., 2021; Lee, 2021; Michas et al., 2013).

Nutritional supply for military has been always found different from civilian groups, but basic food guidelines remain same, as servicemen face stressful conditions like extreme heat and cold, low oxygen, etc. Being used to a well-disciplined life, it's important to supply them with good nutrition to get maximum output of servicemen. The physical fitness is paramount importance for performing military tasks. Unhealthy dietary habits and obesity have negative impact on fitness and performance of servicemen. A report indicated among civilian adults in USA applied for military service, $54.4 \%$ of them were reported as overweight (Yamane 2007). At US Naval medical center, it was revealed that $53 \%$ is the incidence of overweight/obesity (Gantt et al., 2008; Kaczynski et al., 2020). The mean BMI in Finland military was 26.02\% (Overweight), while in Greek army (26.5\%) and (4.7\%) were rated overweight and obese, respectively (McLaughlin and Wittert, 2009). Similarly, a study has also reported in Saudi Arabian military, due to unhealthy dietary habits and low exercise, the incidence of overweight and obesity was documented to be 40.9 and $29 \%$, respectively. Also, more alarming is central obesity that was reported about 42\% (Horaib et al., 2013).

Recently, in Pakistan deployment and operational duties of servicemen become more tough and multifactorial as they are now deployed at almost all types of terrains and situations which one can think of, like the highest battle ground in the world which is Siachen, deserts of Sind and Punjab, Arabian sea, plains of Punjab and Khyber Pakhtunkhwa (KPK), and the barren mountains of Baluchistan and Federally Administered Tribal Areas (FATA). This further emphasizes importance of nutritional assessment of Pakistani soldier so that they should be provided with healthy meal to keep them fit to better perform in the given task in befitting manner. There is need to develop special rations keeping in view the different areas of deployment as same ration scale and menu could not be given to troops deployed at different terrains. Additionally, the servicemen deployed in field are facing with more environmental hazards and stress than the past. Also, the experts are now agreeing after the outcome of various research results, that nutritional intervention is helpful in preventing and treating injury (Freedman et al., 2019; Jones et al., 2012).
Till date research literature on obesity in military populations reveals successful campaigns have been ones which include regular exercise, eating in healthy way, sound sleep and self- motivation. Increasing age has negative impact on nutritional status due to the fact that physical endurance decreases with age while dietary intake almost remains same. A study carried out among young men seeking induction in Pakistan servicemen reported overweight/obesity at the rate of $11.2 \%$ among healthy adults. Also, effective awareness campaigns which should include knowledge about healthy diet and regular aerobic exercise is needed in young adults to promote public health (Schnettler et al., 2021; Younas et al., 2013).

A study was carried out in one of military garrison of Pakistan to determine obesity and hypertension among healthy males serving in military. In order to carry out our research we have followed WHO standards proposed for body mass index (BMI). The blood pressure (BP) taken in sitting position in left arm in a quiet warm room after five minutes of rest. $\mathrm{BP}>140 / 90 \mathrm{mmHg}$ defined as hypertension. Findings reported out of study group (34.4\%) were overweight and (35.4\%) were obese as well as (9.8\%) were found to be hypertensive indicting that even healthylooking servicemen are suffering from different disease such as obesity and hypertension (Kamran et al., 2016). Considering the scenario, present study has been a step towards realization of importance of dietary habits causing obesity in servicemen contributing towards obesity, and impact it is having on declining fitness level of servicemen. Moreover, study also aimed to assess nutritional status of servicemen in relation to their duty area and feeding habits ultimately contributing towards their performance for the country.

\section{Methodology}

\subsection{Study design and participants}

The study was a cross-sectional survey conducted with collaboration and support of servicemen at Armed Forces Institute of Nutrition and Department of Food Science and Human Nutrition, University of Veterinary and Animal Sciences, Lahore Punjab, Pakistan. The study started in June, 2014 and ended in February, 2016 involving servicemen of various ranks and deployment area for servicemen.

\subsection{Settings of the study}

The target area was whole Pakistan as servicemen are deployed all over the country, special emphasis given to troops deployed at Snow hilly areas, deserts and plains like city cantonments. The three straits formed are as follows; Snow Hilly Areas including Siachen, Gilgit, Skardu, and Waziristan; Desert Areas: It included Pano Aqil, Hyderabad, Chhor, and Rahim Yar Khan and Plains as the city cantonments including Lahore, Karachi, Rawalpindi, and Peshawar.

\subsection{Sampling technique and sample size}

The stratified sampling method was used considering percentage of different ranks i.e. Soldiers, Junior Commissioned Officers and Officers as well as different 
areas of deployment like, Snow Hilly area, desert and plain like city cantonments. The equal numbers of participants selected from each pre-selected deployment area. A total of (2501) servicemen selected for study to cater expected dropout rate of minimum $10 \%$ (required number for study were 2500 by Slovin's Formula). The number of individuals selected from each rank according to their total population in military and deployment area i.e. Soldiers including 1500 ( $7 \%$ of 23,000 approx.), Junior Commissioned Officers including 500 (7\% of 7000 approx.) and officers as 500 (7\% of 7000 approximately).

\subsection{Data collection and nutrition assessment}

The anthropometric measurements of servicemen done at location by trained individuals like physical health assistant who were trained by a team of Master Trainers from Armed Forces Institute of Nutrition and laboratory tests were performed at various Combined Military Hospitals and Armed Forces Institute of Pathology Rawalpindi. The anthropometric parameters including Age (years), Gender, weight $(\mathrm{Kg})$, Height $(\mathrm{cm})$, Body mass index was calculated with help of measuring tape and Waist Circumference $(\mathrm{cm})$ and hip circumference was measured using vernier caliper. Additionally, nutritional history and dietary habits recorded along with dietary recall of last 3 days using a questionnaire and obtained data assessed and compared with international recommendations.

\subsection{Data analysis}

The collected data was analyzed using Statistical Package for Social Sciences (SPSS Inc. Chicago, IL, USA) Version 25.0 by following the guidelines of Steel and Torrie (1997). Descriptive statistic used to define and represent data and the findings reported in percentage \% and frequencies. Multiple linear regression was applied to assess the predictors of obesity (higher body mass index) and waist to hip ration (WHR) among the servicemen at Armed Forces Institute of Nutrition. Results were considered significant at ( $\mathrm{p}$-value $<0.05)$.

\section{Results}

The results indicated among participants, 2501 responded with complete forms indicating a response rate (92.6\%) including Junior Commissioned Officer's 501 (20.03\%), Officers 500 (20\%) and Soldiers as 1,500 (59.9\%). Among these, the servicemen from Cantonments were 915 (36.6\%), from desert $741(29.6 \%)$ as well as from mountains 845 (33.8\%), respectively. Approximately more than three-quarters of the sample were found below the age of 40 years. The mean education years (11) indicate secondary level of education. They were mostly married (78.8\%). Approximately, the three-quarters of soldier performed office type job (71.2) rest were in field and median years of service were from 13 years (Table 1 ).

The results in (Table 2 ) indicated that health-related habits of servicemen. Only one-quarter (25.6\%) of participants were currently doing smoking. Questionnaire containing eating habits based on food frequency questionnaire tool. Participants eating fruits less than
4 days/week and vegetables less than 3 days/week were $24.4 \%$. Only $36 \%$ servicemen were physically active for at least $40 \mathrm{~min} / \mathrm{day}$.

Body mass index (BMI) was used to calculate the health status of participants. Results showed that approximately the three-quarter (74\%) of participants were in normal BMI range and approximately one-quarter were overweight and obese (22.6\%). The mean BMI of participants also showed normal range of BMI $\left(23 \mathrm{~kg} / \mathrm{m}^{2}\right)$. Waist to hip ratio is a

Table 1. Socio-demographic Characteristics of the survey sample $(\mathrm{n}=2,501)$.

\begin{tabular}{|c|c|c|}
\hline Socio-demographic & Frequency & (\%) \\
\hline \multicolumn{3}{|l|}{ Age (Years) } \\
\hline$<30$ & 983 & 39.3 \\
\hline 30 to $<40$ & 1,141 & 45.6 \\
\hline 40 to $<50$ & 368 & 14.7 \\
\hline$\geq 50$ & 9 & 0.4 \\
\hline Mean (SD) & \multicolumn{2}{|c|}{$31.95(6.90)$} \\
\hline \multicolumn{3}{|l|}{ Total Years of Education } \\
\hline Mean (SD) & \multicolumn{2}{|c|}{$11.20(1.60)$} \\
\hline Median (25-75 ${ }^{\text {th }}$ quartiles) & \multicolumn{2}{|c|}{$32(26-37)$} \\
\hline \multicolumn{3}{|l|}{ Marital Status } \\
\hline Un-married & 531 & 21.2 \\
\hline Married & 1,970 & 78.8 \\
\hline Divorced/ Widow & 0 & 0 \\
\hline \multicolumn{3}{|l|}{ Military Rank } \\
\hline Soldier & 1,500 & 60 \\
\hline JCO & 501 & 20 \\
\hline Officer & 500 & 20 \\
\hline \multicolumn{3}{|l|}{ Job Type } \\
\hline Office & 1,780 & 71.2 \\
\hline Filed & 721 & 28.8 \\
\hline \multicolumn{3}{|l|}{ Years of Service } \\
\hline Mean (SD) & \multicolumn{2}{|c|}{$12.93(6.91)$} \\
\hline Median $\left(25-75^{\text {th }}\right.$ quartiles $)$ & \multicolumn{2}{|c|}{$13(7-18)$} \\
\hline
\end{tabular}

Table 2. Smoking, eating and physical activity habits in the survey sample $(n=2501)$.

\begin{tabular}{lcr}
\hline \multicolumn{1}{c}{ Variables } & Frequency & (\%) \\
\hline Smoking & & \\
Non-Smokers & 1,749 & 69.9 \\
Ex-Smokers & 112 & 4.5 \\
Smokers & 640 & 25.6 \\
Eat Fruits <4 days a week & 611 & 24.4 \\
Eat vegetables <3 days a week & 611 & 24.4 \\
Practice Physical Activity at & 915 & 36.6 \\
least <40 minutes daily & & \\
\hline
\end{tabular}


quick measure of fat distribution that may help indicate person's overall health. Approximately $85 \%$ of participants had normal waist to hip ratio. Median of waist to hip ratio was 0.85 that was below 1 showing normal range (Table 3 ).

The results in (Table 4 ) represent multiple linear regression model for body mass index which reported statistically significant independent predictors of BMI were age (0.007) and eating fruits less than 3 days/week. However, eating vegetables less than 3 serving per day was inversely related to the BMI as indicated by (B-0.74). The physical activity less than 40 min per week was borderline significant.

The waist to hip ratio and its dependent predictors presented in (Table 5) indicated that age (0.000), rank (0.001) and physical activity (0.001) are significant predictors of WHR but physical activity negatively related to the WHR as indicated by (B-0.004). However, eating

Table 3. Parameters of obesity in the survey sample ( $n=2501)$.

\begin{tabular}{|c|c|c|}
\hline Variables & Frequency & (\%) \\
\hline \multicolumn{3}{|c|}{ Body Mass Index (BMI) $\mathrm{kg} / \mathrm{m}^{2}$} \\
\hline Underweight $(<18.5)$ & 73 & 2.9 \\
\hline Normal (18.5-24.9) & 1,860 & 74.4 \\
\hline Overweight (25-29.9) & 536 & 21.4 \\
\hline Obese (30-24.9) & 31 & 1.2 \\
\hline Morbid Obese (35+) & 1 & 0.0 \\
\hline Mean (SD) & \multicolumn{2}{|c|}{$23.12(2.74)$} \\
\hline Median (25-75 ${ }^{\text {th }}$ quartiles) & \multicolumn{2}{|c|}{$22.8(21.2-24.8)$} \\
\hline \multicolumn{3}{|l|}{ Waist/hip ratio (WHR) } \\
\hline Normal $(<0.9)$ & 2,119 & 84.7 \\
\hline $\operatorname{High}\left(0.9^{+}\right)$ & 382 & 15.3 \\
\hline Mean (SD) & \multicolumn{2}{|l|}{$0.86(0.03)$} \\
\hline Median (25-75 ${ }^{\text {th }}$ quartiles) & \multicolumn{2}{|c|}{$0.85(0.84-0.88)$} \\
\hline
\end{tabular}

vegetables less than 3 serving per day was inversely related to the BMI as indicated by (B-0.74). Physical activity less than 40 min per week was borderline significant.

\section{Discussion}

The study was first of its kind to assess nutritional parameters of Pakistani servicemen in relation to their duty area and feeding habits. The prevalence of overweight/ obesity in Pakistan servicemen reported to be $23.4 \%$ which is out of 2501 individuals, 550 (21\%) overweight, 36 (1.4\%) are obese and $30(1.2 \%)$ are underweight. The results also reported overweight individuals are more than underweight servicemen and similarly a study on Indian air force showed more overweight and underweight servicemen. A comparison with other contemporary militaries showed that the ratio of overweight/obesity of Pakistan is quite healthy except Malaysia and Poland as reported in the literature. The published literature also reveals that ratio of underweight is quiet less as compared to other countries which signify the fact that dietary needs of soldiers are looked after in a befitting manner. Comparing the BMI values with civilian adults, more were obese as compared to overweight (Varte et al., 2011).

This is on the lowered side as compared to other contemporary armies and the general population, the main reason being that in this part of the world the military jobs are considered to be prestigious and a sign of honor, and large number of youth apply for armed forces jobs, due to which the physical standards for induction in the armed forces are quiet stingy and the highest BMI for induction is 22.5 and later on the tough routine with main emphasis on the physical training and fitness keep them fit during the early period of service and the same trend has been noted in the study too (Blair, 2009; Chen and Antonelli, 2020; Chudhary et al., 2020; Jayne et al., 2021).

The prevalence of overweight in case of Officers, out of total 140, the maximum number 84 (60\%) are in the age group 31-40 years, while in case of Junior

Table 4. Multiple Linear regression for Body Mass Index (BMI).

\begin{tabular}{|c|c|c|c|c|c|c|c|}
\hline \multirow{2}{*}{ Variables } & \multicolumn{2}{|c|}{$\begin{array}{l}\text { Unstandardized } \\
\text { Coefficients }\end{array}$} & \multirow{2}{*}{$\begin{array}{c}\text { Standardized } \\
\text { Coefficients }\end{array}$} & \multirow{2}{*}{ T value } & \multirow{2}{*}{ P-Value } & \multicolumn{2}{|c|}{$\begin{array}{l}\text { 95\% Confidence Interval } \\
\text { for B }\end{array}$} \\
\hline & $\begin{array}{l}\text { Odd Ratio } \\
\text { (B) }\end{array}$ & $\begin{array}{l}\text { Standard } \\
\text { Error }\end{array}$ & & & & Lower & Upper \\
\hline (Constant) & 19.982 & 1.175 & & 17.009 & $0.000^{*}$ & 17.679 & 22.286 \\
\hline Age (years) & 0.151 & 0.056 & 0.382 & 2.681 & $0.007^{*}$ & 0.041 & 0.262 \\
\hline Years of Service & -0.008 & 0.056 & -0.019 & -0.138 & 0.891 & -0.117 & 0.102 \\
\hline Rank & -0.025 & 0.117 & -0.007 & -0.213 & 0.832 & -0.255 & 0.205 \\
\hline Smoking & 0.03 & 0.104 & 0.006 & 0.287 & 0.774 & -0.175 & 0.235 \\
\hline $\begin{array}{l}\text { Physical Activity } \\
\text { (<40 minutes) }\end{array}$ & -0.189 & 0.108 & -0.033 & -1.741 & 0.082 & -0.401 & 0.024 \\
\hline $\begin{array}{l}\text { Vegetables (<3 } \\
\text { Servings/ Day) }\end{array}$ & -0.74 & 0.21 & -0.116 & -3.521 & $0.000^{*}$ & -1.152 & -0.328 \\
\hline
\end{tabular}

r-square: 0.144, Model ANOVA: F-69.674, p<0.000*. 
Table 5. Multiple Linear regression for Waist to Hip ratio (WHR).

\begin{tabular}{|c|c|c|c|c|c|c|c|}
\hline \multirow[t]{2}{*}{ Variables } & \multicolumn{2}{|c|}{$\begin{array}{l}\text { Unstandardized } \\
\text { Coefficients }\end{array}$} & \multirow{2}{*}{$\begin{array}{l}\text { Standardized } \\
\text { Coefficients }\end{array}$} & \multirow[t]{2}{*}{ t value } & \multirow[t]{2}{*}{ P-Value } & \multicolumn{2}{|c|}{$\begin{array}{l}\text { 95\% Confidence Interval } \\
\text { for B }\end{array}$} \\
\hline & B & Std. Error & & & & Lower & Upper \\
\hline (Constant) & 0.828 & 0.004 & & 214.056 & $0.000^{*}$ & 0.821 & 0.836 \\
\hline Age (years) & 0.001 & 0 & 0.29 & 14.449 & $0.000^{*}$ & 0.001 & 0.001 \\
\hline Rank & 0.002 & 0.001 & 0.062 & 3.205 & $0.001^{*}$ & 0.001 & 0.003 \\
\hline Smoking & -0.001 & 0.001 & -0.018 & -0.904 & 0.366 & -0.003 & 0.001 \\
\hline $\begin{array}{l}\text { Physical Activity (<40 } \\
\text { minutes) }\end{array}$ & -0.004 & 0.001 & -0.065 & -3.42 & $0.001^{*}$ & -0.006 & -0.002 \\
\hline
\end{tabular}

r-square: 0.104, Model ANOVA: F-72.110, p<0.000*.

Commissioned Officers, out of total 152 the maximum number $83(69.2 \%)$ are in age group $41-50$ years. In case of Soldiers the maximum number 158 (61.2\%) out of 258 , fall in the age group 31-40 years. In case of the prevalence of obesity, the maximum number i.e. $27(75 \%)$ out of 36 , fall in the age group 31-40 years for all the ranks. All the underweight individuals are soldiers and they are in the age group 25-30 years. When we take into account the place of duty and nature of duty, the maximum number (60\%) of excess weight individuals from all the ranks are in the cantonment areas who are deployed on sedentary and peace time jobs/duties. The maximum study subjects been eating from soldier/JCO's/officer mess (94.6\%) as in Table 3, signifying that high caloric food is freely available for consumption. The results compared with an Iranian study showed that with increase in age overweight and obesity rate also increase (Janghorbani et al., 2007).

Unlike many Armed forces in the west, the induction in Pakistan Armed Forces is according to approved weight/ height/age and body size (lean, medium and heavy build), which ensures that all the recruits who are inducted into the military have nutritional status are under the BMI of 23. This is due to fact that large number of individuals applies for these jobs due to high prevalence of unemployment and secondly military jobs considered to be prestigious in Pakistan and people feel honored to serve as defenders of the country. Due to this fact we have to look into the routine of daily physical exercises/activities and train along with the provision of a balanced diet, as all the recruits are in good form and healthy BMI when they are inducted and during the service with increasing age and senior ranks, the trend of overweight/obesity comes into play with increasing frequency (Gualano et al., 2010).

Cigarette smoking is an established risk factor for many diseases although it is amenable to prevention. The rates of smoking have shown decreasing trends in adults in many countries since 19652 , yet the rates at which youngsters, particularly military recruits start smoking are on the rise. This has been attributed to the use of smoking as a means of coping with stress experienced in military settings, to the extent that smoking has been alluded to as "part of the military culture" (Nelson and Pederson, 2008). In military settings smoking is used to combat anxiety, monotony, lack of sleep, and peer influence, which is another important reason for smoking 4 . The military has, therefore, with the large numbers, dispersion throughout the world, and high receptiveness been the target of the tobacco industry for decades (Joseph et al., 2005). Current smokers in our study were $25 \%$ which was approximately one fourth part of the military personal. A study was done on Saudi Arabian soldiers to determine smoking and its associated effects on soldiers. The result showed that currently $35 \%$ of the military men are doing smoking. Navy personnel had a higher risk of being current smokers (40.6\%), and the air defense the lowest risk (31.0\%) (Al-Khashan et al., 2014).

Physical fitness of someone includes psychological, behavioral, medical, nutritional, spiritual, and social health. Regular exercise can have a constructive impact on social health. It is very much imperative that military servicemen be physically fit. The physical fitness level required by a military service member is higher than that of the general population due to the diverse nature of military missions and the large loads carried by service members. In our study only $36 \%$ military officers were involved in physical activity less than 40 minutes per day. Likewise, study done on Slovakian military officers showed their military officers also had quite low aerobic endurance (Papay and Simonek, 2017). Physical fitness is composed of the four components: endurance, mobility, strength, and flexibility. Training should include all four components supported by a foundation of core strength and be based on mission tasks the service member is required to perform. The four components of physical fitness training plus performance monitoring and injury surveillance/prevention must be well understood and included as part of all military physical fitness programs to ensure our men and women in uniform are properly prepared to accomplish any mission safely and effectively (Roy et al., 2010).

Promoting healthy eating among Soldiers is a priority to the Army due to the link between nutrition and performance. The Army typically uses nutrition education to encourage Soldiers to make healthier food choices with low emphasis on other psychosocial determinants of food choice behaviors. Due to the association between nutrition and performance, multiple guidelines and polices dictating nutritional standards has been set by the army. The Army typically employs standard nutrition education methods to encourage Soldiers to make healthy lifestyle choices, but even in the highly structured environment of the Army, 
lifestyle habits and individual choice ultimately govern whether or not soldiers adhere to recommendations (Jayne et al., 2018). As nutrition is a critical element of Soldier health and performance. Food choices, meal timing, and dietary intake behaviors contribute to nutritional fitness. Food frequency questionnaire was used to evaluate military personal dietary habits. The study results showed that approximately one quarter (24\%) of soldiers eating fruits less than 4 days per week and vegetables less than 3 days per week. A 2013 study on U.S. army soldiers found only $38 \%$ and $22 \%$ of Soldiers met the recommendations for fruit and vegetables, respectively (Purvis et al., 2013).

\section{Conclusion}

The study findings indicated that approximately $1 / 5^{\text {th }}$ of servicemen were found overweight and only $1 / 3^{\text {rd }}$ of them were physically active for at least $<40$ minutes per day. Age and fruits consumption directly related to body mass index. Age and rank were directly related to waist to hip ratio. Physical activity was inversely related to WHR and vegetable consumption was inversely related to BMI. By analyzing current nutrition status, it is concluded that there is need to modify eating patterns and habits as well as improving physical activity on daily basis.

\section{References}

ADAMS, M.M., 2020 [viewed 7 April 2021 ]. Identifying protective factors against overweight and obesity within the social environment of women with low incomes [online]. Louisville: University of Louisville, 205 p. Doctoral Dissertation in Social Work. Available from: https://ir.library.louisville.edu/etd/3392/

AL-KHASHAN, H.I., AL SABAAN, F.S., AL NASSER, H.S., AL BURAIDI, A.A., AL AWAD, A.D., HORAIB, G.B., AL OBAIKAN, A.H. and MISHRIKY, A.M., 2014. The prevalence of smoking and its associated factors among military personnel in Kingdom of Saudi Arabia: a national study. Journal of Family \& Community Medicine, vol. 21, no. 3, pp. 147-153. http://dx.doi.org/10.4103/22308229.142966. PMid:25374464.

ASGHAR, M., BUTT, M., AKBAR, A., AZAM, H., ZAHRA, I., WASEEM, M. and MALIK, A., 2021. Stature prediction of punjab population (Pakistan) from hand, forearm and foot measurements. Biological and Clinical Sciences Research Journal, vol. 2021, no. 1, e010.

BLAIR, S.N., 2009. Physical inactivity: the biggest public health problem of the 21st century. British Journal of Sports Medicine, vol. 43, no. 1, pp. 1-2. http://dx.doi.org/10.1136/bjsm.2009.059360. PMid:19136507.

CHEN, P.-J. and ANTONELLI, M., 2020. Conceptual models of food choice: influential factors related to foods, individual differences, and society. Foods, vol. 9, no. 12, pp. 1898. http:// dx.doi.org/10.3390/foods9121898. PMid:33353240.

CHUDHARY, H., AMIN, A., MALIK, M., HAFEEZ, M., RANA, M. and MALIK, A., 2020. Risk assessment of non-conventional contributory factors in onset of diabetes mellitus type II. Biological and Clinical Sciences Research Journal, vol. 2020, e036.

FREEDMAN, D.A., BELL, B.A., CLARK, J.K., SHARPE, P.A., TRAPL, E.S., BORAWSKI, E.A., PIKE, S.N., ROUSE, C. and SEHGAL, A.R., 2019. Socioecological path analytic model of diet quality among residents in two urban food deserts. Journal of the Academy of Nutrition and Dietetics, vol. 119, no. 7, pp. 1150-1159. http:// dx.doi.org/10.1016/j.jand.2019.02.012. PMid:31031105.

GANTT, C.J., NEELY, J.A., VILLAFANA, I.A., CHUN, C.S. and GHARABAGHLI, S.M., 2008. Analysis of weight and associated health consequences of the active duty staff at a major Naval medical center. Military Medicine, vol. 173, no. 5, pp. 434-440. http://dx.doi.org/10.7205/MILMED.173.5.434. PMid:18543563.

GUALANO, B., PINTO, A.L.S., PERONDI, B., PRADO, D.M.L., OMORI, C., ALMEIDA, R.T., SALLUM, A.M.E. and SILVA, C.A.A., 2010. Evidence for prescribing exercise as treatment in pediatric rheumatic diseases. Autoimmunity Reviews, vol. 9, no. 8, pp. 569-573. http://dx.doi.org/10.1016/j.autrev.2010.04.001. PMid:20388559.

HORAIB, G.B., AL-KHASHAN, H.I., MISHRIKY, A.M., SELIM, M.A., ALNOWAISER, N., BINSAEED, A.A., ALAWAD, A.D., AL-ASMARI, A.K. and ALQUMAIZI, K., 2013. Prevalence of obesity among military personnel in Saudi Arabia and associated risk factors. Saudi Medical Journal, vol. 34, no. 4, pp. 401-407. http://dx.doi. org/10.1177/2040622319878997. PMid:23552594.

JANGHORBANI, M., AMINI, M., WILLETT, W.C., MEHDI GOUYA, M., DELAVARI, A., ALIKHANI, S. and MAHDAVI, A., 2007. First nationwide survey of prevalence of overweight, underweight, and abdominal obesity in Iranian adults. Obesity, vol. 15, no. 11, pp. 2797-2808. http://dx.doi.org/10.1038/oby.2007.332. PMid:18070771.

JAYNE, J. M., FRONGILLO, E. A., TORRES-MCGEHEE, T. M., EMERSON, D. M., GLOVER, S. H. and BLAKE, C. E., 2018. A healthy eating identity is associated with healthier food choice behaviors among US Army soldiers. Military Medicine, vol. 183, no. 11, pp. e666-e670. https://doi.org/10.1093/milmed/usy056.

JAYNE, J.M., KARL, J.P., MCGRAW, S.M., O'CONNOR, K., DICHIARA, A.J. and COLE, R.E., 2021. Eating behaviors are associated with physical fitness and body composition among US army soldiers. Journal of Nutrition Education and Behavior, vol. 53, no. 6, pp. 480-488. http://dx.doi.org/10.1016/j.jneb.2021.01.013. PMid:33674236.

JONES, N., SEDDON, R., FEAR, N.T., MCALLISTER, P., WESSELY, S. and GREENBERG, N., 2012. Leadership, cohesion, morale, and the mental health of UK Armed Forces in Afghanistan. Psychiatry, vol. 75, no. 1, pp. 49-59. http://dx.doi.org/10.1521/ psyc.2012.75.1.49. PMid:22397541.

JOSEPH, A.M., MUGGLI, M., PEARSON, K.C. and LANDO, H., 2005. The cigarette manufacturers' efforts to promote tobacco to the US military. Military Medicine, vol. 170, no. 10, pp. 874-880. http://dx.doi.org/10.7205/MILMED.170.10.874. PMid:16435763.

KACZYNSKI, A.T., EBERTH, J.M., STOWE, E.W., WENDE, M.E., LIESE, A.D., MCLAIN, A.C., BRENEMAN, C.B. and JOSEY, M.J., 2020. Development of a national childhood obesogenic environment index in the United States: differences by region and rurality. The International Journal of Behavioral Nutrition and Physical Activity, vol. 17, no. 1, pp. 83. http://dx.doi.org/10.1186/s12966020-00984-X. PMid:32615998.

KAMRAN, S.M., IFTIKHAR, R. and ROSHAN, R., 2016. Frequency of obesity and hypertension in armed forces: it is time to face reality. Pakistan Armed Forces Medical Journal, vol. 66, pp. S36-S40.

LEE, K.E., 2021. Factors promoting physical fitness and healthy eating in extrinsically motivated populations: a comparative study. Arizona: University of Arizona.

MCLAUGHLIN, R. and WITTERT, G., 2009. The obesity epidemic: implications for recruitment and retention of defence force personnel. Obesity Reviews, vol. 10, no. 6, pp. 693-699. http:// dx.doi.org/10.1111/j.1467-789X.2009.00601.x. PMid:19486307. 
MICHAS, G., KAMPOURAS, A., KOKOLIOS, M., DROSATOS, I.A. and MICHA, R., 2013. Prevalence of overweight and obesity among greek army recruits. European Journal of Internal Medicine, vol. 8, no. 1, pp. 28-34. http://dx.doi.org/10.1016/ S0953-6205(11)60253-7.

MONTAIN, S.J., CARVEY, C.E. and STEPHENS, M.B., 2010. Nutritional fitness. Military Medicine, vol. 175, no. 8, pp. 65-72. http:// dx.doi.org/10.7205/MILMED-D-10-00127.

NELSON, J.P. and PEDERSON, L.L., 2008. Military tobacco use: a synthesis of the literature on prevalence, factors related to use, and cessation interventions. Nicotine $\mathcal{E}$ Tobacco Research, vol. 10, no. 5, pp. 775-790. http://dx.doi. org/10.1080/14622200802027123. PMid:18569751.

PAPAY, J. and SIMONEK, J., 2017. Physical fitness of soldiers in the Armed Forces of Slovakia. Defence Life Science Journal, vol. 2 , no. 1, pp. 30-36. http://dx.doi.org/10.14429/dlsj.2.9795.

PURVIS, D.L., LENTINO, C.V., JACKSON, T.K., MURPHY, K.J. and DEUSTER, P.A., 2013. Nutrition as a component of the performance triad: how healthy eating behaviors contribute to soldier performance and military readiness. U.S. Army Medical Department Journal, vol. 2013, pp. 66-78. http://dx.doi. org/10.1016/j.jand.2013.03.002. PMid:24146244.

ROY, T.C., SPRINGER, B.A., MCNULTY, V. and BUTLER, N.L., 2010. Physical fitness. Military Medicine, vol. 175, no. 8, pp. 14-20. http://dx.doi.org/10.7205/MILMED-D-10-00138.

SCHNETTLER, B., ROBINOVICH, J., ORELLANA, L., MIRANDA-ZAPATA, E., ODA-MONTECINOS, C., HUECHE, C., LOBOS, G., ADASMEBERRÍOS, C., LAPO, M., SILVA, J., OSSA, X. and MUÑOZ, S.,
2021. Eating styles profiles in Chilean women: A Latent Profile Analysis. Appetite, vol. 163, no. 105211, pp. 105211. http://dx.doi. org/10.1016/j.appet.2021.105211. PMid:33775788.

STEEL, R.G. and TORRIE, J.H., 1997. Principles and procedures of statistics, a biometrical approach. Kogakusha: McGraw-Hill.

TRIBUNE, 2014. Pakistan 9th most obese country: study. Express Tribune Pakistan, Karachi, 29 may.

VARTE, L.R., MAJUMDAR, D., RAWAT, S. and SINGH, I., 2011. Status of obesity in terms of body mass index among indian air force personnel. Al Ameen Journal of Medical Sciences, vol. 4, no. 4, pp. 379-385. http://dx.doi.org/10.1016/S0377-1237(09)80090-7.

WANG, J., LUO, B., XIE, Y., HU, H., FENG, L. and LI, Z.N., 2014. Evaluation methods on the nutritional status of stroke patients. European Review for Medical and Pharmacological Sciences, vol. 18, no. 24, pp. 3902-3907. PMid:25555882.

YAMANE, G.K., 2007. Obesity in civilian adults: potential impact on eligibility for US military enlistment. Military Medicine, vol. 172, no. 11, pp. 1160-1165. http://dx.doi.org/10.7205/ MILMED.172.11.1160. PMid:18062389.

YOUNAS, M., KHAN, A.A., SIDDIQUE, M. and AHSAN, R.A., 2013. Obesity/overweight among healthy adult males seeking employment in pakistan army. Pakistan Armed Forces Medical Journal, vol. 63, no. 4, pp. 534-538. http://dx.doi. org/10.1186/1471-2458-11-724. 